\title{
Microbial reduction of chromate in the presence of nitrate by three nitrate respiring organisms
}

\author{
Peter Chovanec ${ }^{1,2}$, Courtney Sparacino-Watkins ${ }^{2}$, Ning Zhang ${ }^{3}$, Partha Basu ${ }^{2 *}$ and John F Stolz ${ }^{1,3 *}$ \\ Department of Biological Sciences, Duquesne University, Pittsburgh, PA, USA \\ 2 Department of Chemistry and Biochemistry, Duquesne University, Pittsburgh, PA, USA \\ ${ }^{3}$ Center for Environmental Research and Education, Duquesne University, Pittsburgh, PA, USA
}

Edited by:

Jennifer Pett-Ridge, Lawrence

Livermore National Lab, USA

\section{Reviewed by:}

Yuri A. Gorby, University of Southern

California, USA

Santosh Mohanty, Indian Institute of

Soil Science, India

${ }^{*}$ Correspondence:

Partha Basu, Department of Chemistry and Biochemistry,

Duquesne University, Pittsburgh, PA 15282, USA.

e-mail: basu@duq.edu;

John F. Stolz, Department of

Biological Sciences and Center for

Environmental Research and

Education, Duquesne University,

Pittsburgh, PA 15282, USA.

e-mail:stolz@duq.edu
A major challenge for the bioremediation of toxic metals is the co-occurrence of nitrate, as it can inhibit metal transformation. Geobacter metallireducens, Desulfovibrio desulfuricans, and Sulfurospirillum barnesii are three soil bacteria that can reduce chromate $[\mathrm{Cr}(\mathrm{VII})]$ and nitrate, and may be beneficial for developing bioremediation strategies. All three organisms respire through dissimilatory nitrate reduction to ammonia (DNRA), employing different nitrate reductases but similar nitrite reductase (Nrf). G. metallireducens reduces nitrate to nitrite via the membrane bound nitrate reductase (Nar), while $S$. barnesii and $D$. desulfuricans strain 27774 have slightly different forms of periplasmic nitrate reductase (Nap). We investigated the effect of DNRA growth in the presence of $\mathrm{Cr}(\mathrm{VI})$ in these three organisms and the ability of each to reduce $\mathrm{Cr}(\mathrm{VI})$ to $\mathrm{Cr}(\mathrm{III})$, and found that each organisms responded differently. Growth of G. metallireducens on nitrate was completely inhibited by $\mathrm{Cr}(\mathrm{VI})$. Cultures of $D$. desulfuricans on nitrate media was initially delayed $(48 \mathrm{~h})$ in the presence of $\mathrm{Cr}(\mathrm{VI})$, but ultimately reached comparable cell yields to the non-treated control. This prolonged lag phase accompanied the transformation of $\mathrm{Cr}(\mathrm{VI})$ to $\mathrm{Cr}(\mathrm{III})$. Viable G. metallireducens cells could reduce $\mathrm{Cr}(\mathrm{VI})$, whereas $\mathrm{Cr}(\mathrm{VI})$ reduction by $\mathrm{D}$. desulfuricans during growth, was mediated by a filterable and heat stable extracellular metabolite. S. barnesii growth on nitrate was not affected by $\mathrm{Cr}(\mathrm{VI})$, and $\mathrm{Cr}(\mathrm{VI})$ was reduced to $\mathrm{Cr}(\mathrm{III})$. However, $\mathrm{Cr}(\mathrm{VI})$ reduction activity in $\mathrm{S}$. barnesii, was detected in both the cell free spent medium and cells, indicating both extracellular and cell associated mechanisms. Taken together, these results have demonstrated that $\mathrm{Cr}(\mathrm{VI})$ affects DNRA in the three organisms differently, and that each have a unique mechanism for $\mathrm{Cr}(\mathrm{VI})$ reduction.

Keywords: chromate reduction, nitrate respiration, bioremediation, nitrate reductase, nitrite reductase

\section{INTRODUCTION}

Chromium (atomic number 24) is an enigmatic transition metal that is abundant (average concentration $\sim 100 \mu \mathrm{g} / \mathrm{g}$ ) within the Earth's crust, yet has no known natural biological role. Chromium is found in silicates as well as in mixed metal minerals, and is enriched in certain soils (Cox, 1995). Like the other group VI metal ions, such as molybdenum and tungsten, chromium can exist in a variety of oxidation states, with $\mathrm{Cr}(\mathrm{III})$ and $\mathrm{Cr}(\mathrm{VI})$ as the most prevalent. Trivalent chromium, $\mathrm{Cr}$ (III), occurs naturally in rocks, plants, and soil. Hexavalent chromium, $\mathrm{Cr}(\mathrm{VI})$, is a common by-product of industrial processes, e.g., electroplating, leather tanning, and wood preservation, and in nuclear waste (Pattanapipitpaisal et al., 2001). Unfortunately, $\mathrm{Cr}(\mathrm{VI})$ is also the most mobile and the more toxic form of chromium. The mobility of $\mathrm{Cr}(\mathrm{VI})$ in the environment is due to the intrinsically high water-solubility. $\mathrm{Cr}(\mathrm{III})$ is insoluble at physiological $\mathrm{pH}$ and thus less mobile (Ball and Nordstrom, 1998). The mechanism of chromium toxicity in humans is not completely understood, however, $\mathrm{Cr}(\mathrm{VI})$ is believed to be more toxic than $\operatorname{Cr}(\mathrm{III})$ due to its ability to get into the cells using phosphate transporters. $\mathrm{Cr}(\mathrm{VI})$ is a well-known mutagen and potential carcinogen (Losi et al., 1994). Because Cr(III) exhibits less toxicity and reduced mobility within the environment, many bioremediation strategies focus on the transformation of Cr(VI) into Cr(III) (Kanmani et al., 2012).

The chemical transformation of $\mathrm{Cr}(\mathrm{VI})$ into $\mathrm{Cr}(\mathrm{III})$ is well understood. From a chemical view point, $\mathrm{Cr}(\mathrm{VI})$ is more stable under oxidizing conditions and $\mathrm{Cr}(\mathrm{III})$ is more stable under reducing conditions. Chromium speciation is also dependent on $\mathrm{pH}$ with $\mathrm{Cr}(\mathrm{III})$ more prevalent at neutral $\mathrm{pH}$, although multiple species of chromium do exist in equilibrium (Ball and Nordstrom, 1998). Altering the redox environment of chromium contaminated sediments, to stabilize $\mathrm{Cr}(\mathrm{III})$, is a potential means for $\mathrm{Cr}(\mathrm{VI})$ remediation. The challenge of redox induced $\mathrm{Cr}(\mathrm{III})$ precipitation is creating a practical method for treating large areas of contaminated sediment and water, without significantly impacting the natural biota.

Many remediation strategies are based on microbial transformation (Turick et al., 1996; Viamajala et al., 2002a,b; Camargo et al., 2003a,b; Kanmani et al., 2012) and have included schemes involving microbial consortia (Pattanapipitpaisal et al., 2001; Battaglia-Brunet et al., 2002; Arias and Tebo, 2003; Cheung and Gu, 2003), and pure cultures (Nepple et al., 2000; Park et al., 2000; 
McLean and Beveridge, 2001; Wielinga et al., 2001; Kwak et al., 2003). The microbial reduction of $\mathrm{Cr}(\mathrm{VI})$ to $\mathrm{Cr}(\mathrm{III})$ has been demonstrated in both facultative aerobes, e.g., Escherichia coli, Shewanella alga, Bacillus sp., Ochrobactrum tritici, Pseudomonas putida, Cellulomonas sp., and strict anaerobes, e.g., Geobacter metallireducens, Desulfovibrio vulgaris. These bacteria appear to utilize different molecular mechanisms for $\mathrm{Cr}(\mathrm{VI})$ reduction (Lovley et al., 1993; Park et al., 2000; Branco et al., 2008). Aerobic $\mathrm{Cr}(\mathrm{VI})$ reduction is mediated by several different soluble cytoplasmic enzymes. Suzuki et al. (1992) described the purification of a $\mathrm{NAD}(\mathrm{P}) \mathrm{H}$-dependent $\mathrm{Cr}(\mathrm{VI})$ reductase enzyme from Pseudomonas ambigua; which was later shown to be a homolog of nitroreductase (Kwak et al., 2003). A smaller (20 kDa) enzyme purified from $P$. putida was also found to be $\mathrm{NAD}(\mathrm{P}) \mathrm{H}$ and $\mathrm{NADH}$ dependent and inhibited by sulfate (Park et al., 2000). Anaerobic reduction of $\mathrm{Cr}(\mathrm{VI})$ can also be mediated by several different redox active proteins including low potential c-type cytochromes and hydrogenases (Michel et al., 2001; Chardin et al., 2003). Studies on Desulfovibrio species identified a tetraheme c-type cytochrome with $\mathrm{Cr}$ (VI) reduction activity (Chardin et al., 2003). Other hemec proteins that have been implicated in $\mathrm{Cr}(\mathrm{VI})$ reduction include an octaheme cytochrome $c_{3}$ (Czjzek et al., 1996), a multiheme (16) cytochrome Hmc (Bruschi et al., 1992), and a non-heme cytochrome (Saraiva et al., 1999). The sulfate-reducing Desulfovibrionaceae family are also known to utilize hydrogenases in $\mathrm{Cr}(\mathrm{VI})$ reduction (Lovley and Phillips, 1994; Chardin et al., 2003).

Currently, the implementation of microbial chromium bioremediation has encountered two challenges: (1) the sensitivity of the microbe to elevated levels of chromium and (2) the inhibitory effects of co-contaminates, such as nitrate, on the reduction of $\mathrm{Cr}(\mathrm{VI})$ to $\mathrm{Cr}(\mathrm{III})$. Several chromium resistant microbes have been identified (Morales et al., 2007; Mehta and Vaidya, 2010). In Rhodobacter sphaeroides, chromium resistance has been linked to reduction via a non-specific $\mathrm{FADH}_{2}$-dependent metal reductase, and is thought to be for internal redox control and detoxification (Moore and Kaplan, 1992, 1994). It is important to note that $\mathrm{Cr}(\mathrm{VI})$ resistance is not necessarily coupled to $\mathrm{Cr}(\mathrm{VI})$ reduction, but rather to an efflux system to remove chromium from cells (Nies and Silver, 1995). Thus an organism's response to $\mathrm{Cr}(\mathrm{VI})$ can be different (Ramírez-Díaz et al., 2008). Further complicating the situation is the fact that many contaminated sites not only contain chromium, but also elevated levels of other highly oxidized chemicals, such as nitrate. The biotransformation of chromium in complex mixtures can be impacted in three ways: (1) competitive alternative electron acceptor (inhibiting transformation), (2) cometabolism (i.e., concomitant reduction, stimulating transformation), and (3) induction of specific proteins and pathways involved in oxidation/reduction reactions (stimulating transformation). The third scenario would be the most desirable for bioremediation of nitrate and chromate contaminated environments.

We investigated the effect of $\mathrm{Cr}(\mathrm{VI})$ reduction on dissimilatory nitrate reduction to ammonia (DNRA) by soil bacteria because nitrate is commonly found with $\mathrm{Cr}(\mathrm{VI})$ at many contaminated sites. Bacteria reduce nitrate into nitrite with nitrate reductase enzymes (Nap or Nar), then nitrite can be transformed into ammonia during DNRA or to nitric oxide during denitrification, by nitrite reductase enzymes (Stolz and Basu, 2002). Nitric oxide may be further enzymatically reduced to nitrous oxide and dinitrogen gas in the latter process (Zumft, 1997). These two different dissimilatory processes, DNRA and denitrification, yield different amounts of energy and reducing equivalents. Nevertheless, nitrate is a powerful antagonist of many metal and metalloid transformations, as it may compete for the available electron donor or act directly by interfering with the enzymatic process. $\mathrm{Cr}(\mathrm{VI})$ is energetically less favorable when compared with nitrate (Ball and Nordstrom, 1998), thus nitrate should inhibit respiratory chromate reduction. Herein we report the impact of nitrate reduction on $\mathrm{Cr}(\mathrm{VI})$ transformation. To investigate these processes, we have focused on three dissimilatory metal reducing organisms that are capable of DNRA: G. metallireducens (Lovley et al., 1993), Desulfovibrio desulfuricans strain 27774 (Liu and Peck, 1981), and Sulfurospirillum barnesii (Oremland et al., 1994).

Despite their shared ability to carry out DNRA, the organisms use different nitrate reductases. G. metallireducens reduces nitrate to nitrite via the membrane bound nitrate reductase (Nar), while D. desulfuricans strain 27774 and S. barnesii have periplasmic nitrate reductases (Nap); their catalytic subunit (NapA) differs significantly in size with $D$. desulfuricans the smallest at $\sim 70 \mathrm{kD}$ (Marietou et al., 2005) and S. barnesii the largest at $\sim 102 \mathrm{kD}$ (Sparacino et al., 2008; Sparacino-Watkins, 2011). All three organisms have a pentaheme nitrite reductase (Nrf) that reduces nitrite to ammonia. We demonstrate here that dissimilatory nitrate reduction in each of these organisms is affected differently by the presence of $\mathrm{Cr}(\mathrm{VI})$ and involves different mechanisms for attenuation.

\section{MATERIALS AND METHODS CULTURES AND GROWTH EXPERIMENTS}

G. metallireducens was grown on freshwater acetate medium with nitrate (FWA-NO ${ }_{3}$ ) as previously described (Lovley et al., 1993) and modified in Senko and Stolz (2001). S. barnesii and D. desulfuricans were grown on SES3 freshwater medium with lactate and nitrate as previously described (Stolz et al., 1997) or FWL-NO 3 , a modified FWA- $\mathrm{NO}_{3}$ medium in which lactate $(10 \mathrm{mM})$ was used as a replacement for acetate as the electron donor and carbon source.

FWA- $\mathrm{NO}_{3}$ and FWL-NO $\mathrm{NO}_{3}$ (for growth of G. metallireducens and $D$. desulfuricans respectively) contained $1.5 \mathrm{~g} \mathrm{NH}_{4} \mathrm{Cl}, 0.6 \mathrm{~g}$ $\mathrm{NaH}_{2} \mathrm{PO}_{4}, 0.1 \mathrm{~g} \mathrm{KCl}$, and $2.5 \mathrm{~g} \mathrm{NaHCO}_{3}, 2 \mathrm{~mL}$ of $500 \times$ trace element solution and $2 \mathrm{~mL} 500 \times$ vitamin mix (Lovley and Phillips, $1988)$ in $\sim 1 \mathrm{~L}(996 \mathrm{~mL})$ of distilled water. The medium was adjusted to $\mathrm{pH} 6.8$ with $\mathrm{HCl}$ and dispensed into Wheaton bottles (either 50 or $125 \mathrm{~mL}$ ), and degassed with $80: 20 \mathrm{~N}_{2}: \mathrm{CO}_{2}$ ( 5 min for the liquid, 2 min for the headspace). Bottles were sealed with butyl rubber stoppers and capped with aluminum crimp tops before autoclaving. FWA- $\mathrm{NO}_{3}$ contained acetate $(6.8 \mathrm{~g} / \mathrm{L})$ and $\mathrm{NaNO}_{3}$ $(1.7 \mathrm{~g} / \mathrm{L}) . \mathrm{FWL}-\mathrm{NO}_{3}$ was amended with lactate $(2.72 \mathrm{~mL}$ of a $60 \%$ stock solution) and $\mathrm{NaNO}_{3}(1.7 \mathrm{~g} / \mathrm{L})$. The SES3 medium contained $0.23 \mathrm{~g} \mathrm{~K}_{2} \mathrm{HPO}_{4}, 0.23 \mathrm{~g} \mathrm{KH}_{2} \mathrm{PO}_{4}, 0.46 \mathrm{~g} \mathrm{NaCl}, 0.23 \mathrm{~g}\left(\mathrm{NH}_{4}\right)_{2} \mathrm{SO}_{4}$, $0.12 \mathrm{~g} \mathrm{MgSO}_{4} .7 \mathrm{H}_{2} \mathrm{O}, 10 \mathrm{~g}$ yeast extract, and $4.2 \mathrm{~g} \mathrm{NaHCO}_{3}$, lactate $(2.72 \mathrm{~mL}$ of a $60 \%$ solution), nitrate (as sodium nitrate $1.7 \mathrm{~g}$ ) and $2 \mathrm{~mL} 500 \times$ trace elements, $2 \mathrm{~mL} 500 \times$ vitamin mixture (as above) in $\sim 1 \mathrm{~L}(996 \mathrm{~mL})$ of distilled water. The medium was adjusted to $\mathrm{pH} 7.2$ with $\mathrm{HCl}$ and dispensed into serum bottles, either 50 or 
$125 \mathrm{~mL}$ (Wheaton), and degassed with 80:20 $\mathrm{N}_{2}: \mathrm{CO}_{2}$ (5 min for the liquid, $2 \mathrm{~min}$ for the headspace). Bottles were sealed with butyl rubber stoppers and capped with aluminum crimp tops before autoclaving.

The vitamin mixture $(500 \times$; Lovley and Phillips, 1988) contains biotin, $10 \mathrm{mg} / \mathrm{L}$; folic acid, $10 \mathrm{mg} / \mathrm{L}$; pyridoxine $\mathrm{HCl}, 50 \mathrm{mg} / \mathrm{L}$; riboflavin, $25 \mathrm{mg} / \mathrm{L}$; thiamine $25 \mathrm{mg} / \mathrm{L}$; nicotinic acid, $25 \mathrm{mg} / \mathrm{L}$; pantothenic acid, $25 \mathrm{mg} / \mathrm{L}$; $p$-aminobenzoic acid $25 \mathrm{mg} / \mathrm{L}$; thioctoic acid, $25 \mathrm{mg} / \mathrm{L} ; \mathrm{B} 12,0.5 \mathrm{mg} / \mathrm{L}$. The mineral mixture $(500 \times)$ contains nitrilotriacetic acid, $7.5 \mathrm{~g} / \mathrm{L} ; \mathrm{MgSO}_{4}, 15.0 \mathrm{~g} / \mathrm{L} ; \mathrm{MnCl}_{2}$, $2.22 \mathrm{~g} / \mathrm{L} ; \mathrm{NaCl}, 5.0 \mathrm{~g} / \mathrm{L} ; \mathrm{FeCl}_{3}, 0.335 \mathrm{~g} / \mathrm{L} ; \mathrm{CaCl}_{2} .2 \mathrm{H}_{2} \mathrm{O}, 0.5 \mathrm{~g} / \mathrm{L}$; $\mathrm{CoCl}_{2}, 0.5 \mathrm{~g} / \mathrm{L} ; \mathrm{ZnSO}_{4} .7 \mathrm{H}_{2} \mathrm{O}, 1.36 \mathrm{~g} / \mathrm{L} ; \mathrm{CuSO}_{4} .5 \mathrm{H}_{2} \mathrm{O} 0.05 \mathrm{~g} / \mathrm{L}$; $\mathrm{AlK}\left(\mathrm{SO}_{4}\right)_{2}, 0.05 \mathrm{~g} / \mathrm{L}$; granular boric acid, $0.05 \mathrm{~g} / \mathrm{L} ; \mathrm{Na}_{2} \mathrm{MoO}_{4}$, $0.125 \mathrm{~g} / \mathrm{L} ; \mathrm{NiCl}_{2} .6 \mathrm{H}_{2} \mathrm{O}, 0.125 \mathrm{~g} / \mathrm{L} ; \mathrm{Na}_{2} \mathrm{WO}_{4}, 0.125 \mathrm{~g} / \mathrm{L}$.

Stock solutions of potassium chromate were prepared separately, degassed to remove oxygen, filter sterilized, and then added aseptically, using the Hungate technique, to autoclaved media to a final concentration of $100 \mu \mathrm{M} \mathrm{Cr}(\mathrm{VI})$. The growth kinetics were determined by turbidity (OD at $600 \mathrm{~nm}$ ) on a Perkin Elmer Lambda 2 dual beam spectrophotometer. Kinetic data for growth and chromium reduction were analyzed by Origin 7.5 using non-linear functions using Levenberg-Marquardt algorithm and simplex method implemented in Origin 7.5. Each data set was fit with a single exponential function $\left(y=A_{1} \times \exp \left(-x / t_{1}\right)+y_{0}\right.$ for decay or $y=A_{1} \times \exp \left(x / t_{1}\right)+y_{0}$ for growth) indicating a first order process. Some data pertaining to the $\mathrm{Cr}$ reduction as a function of time were also analyzed by Graph Pad Prism software.

\section{LIVE/DEAD WHOLE CELL AND FILTRATE ASSAYS}

Cells of G. metallireducens, D. desulfuricans, and S. barnesii were grown on nitrate as described above. Three milliliters samples of cells, in log phase of growth and comparable cell numbers, were harvested by centrifugation, washed in Tris buffer $(10 \mathrm{mM}, \mathrm{pH}$ $7.4)$, then resuspended in $3 \mathrm{~mL}$ of fresh medium. Samples $(3 \mathrm{~mL})$ of supernatant were collected via degassed syringe and filtered using $0.2 \mu \mathrm{m}$ polycarbonate Millipore filters and stored under nitrogen gas. The cell suspensions or filtrates $(3 \mathrm{~mL}$ each) were then added to $50 \mathrm{~mL}$ of fresh medium amended with $100 \mu \mathrm{M}$ $\mathrm{Cr}(\mathrm{VI})$ and incubated for $48 \mathrm{~h}$. Heat killed controls were autoclaved for $20 \mathrm{~min}$. Aliquots were removed at $0,2,6,12,24$, and $48 \mathrm{~h}$, and $\mathrm{Cr}(\mathrm{VI})$ concentration determined by the diphenylcarbazide (DPC) method as previously described (Saltzman, 1952).

\section{ELECTRON DONORS FOR CHROMIUM REDUCTION IN $D$. DESULFURICANS}

Cells of $D$. desulfuricans, grown of $\mathrm{FWL}_{-} \mathrm{NO}_{3}$ medium, were harvested by centrifugation, as previously described, then resuspended in $180 \mathrm{~mL}$ bicarbonate buffer at $\mathrm{pH}$ 6.8. Serum bottles $(50 \mathrm{~mL})$ were grouped in triplicate as: control (no cells and no electron donor); cells only, cells with lactate, cells with hydrogen, lactate only, and hydrogen only. The cell suspension $(20 \mathrm{~mL})$ was then added to each bottle in the three groups - cells only, cells with lactate, cells with hydrogen. Bicarbonate buffer $(20 \mathrm{~mL})$ was added to each bottle in the following groups: positive control, lactate only, and hydrogen only. All bottles with the exception those with hydrogen were degassed with $\mathrm{N}_{2}$, while hydrogen bottles were degassed and had their headspace filled with $\mathrm{H}_{2}$. In the lactate samples, $200 \mu \mathrm{L}$ of $1 \mathrm{M}$ lactate was added. Each bottle was sterilized by autoclaving, and was crimp sealed to maintain anaerobic condition, then $200 \mu \mathrm{L}$ of the $10 \mathrm{mM} \mathrm{Cr}(\mathrm{VI})$ stock solution was added to initiate the reduction. At each time point, $3 \mathrm{~mL}$ of sample was withdrawn and the $\mathrm{Cr}(\mathrm{VI})$ content was determined by DPC assay. From each withdrawal three measurements were conducted providing three technical replicates for each biological replicate.

\section{CHROMIUM RESISTANCE IN D. DESULFURICANS}

D. desulfurican was grown for $48 \mathrm{~h}$, then $20 \mathrm{~mL}$ of the culture was transferred to five $25-\mathrm{mL}$ serum bottle under anaerobic conditions. Different concentrations of potassium chromate were then added to each bottle to a final concentration of 25, 50, 75, $100 \mu \mathrm{M}$. In the control experiment, $\mathrm{FWA}^{-\mathrm{NO}_{3}}$ medium was used with potassium chromate without any cells. Cell density was monitored at $600 \mathrm{~nm}$ absorbance with Perkin Elmer UV/VIS spectrometer. Aliquots were withdrawn at a regular time intervals and $\mathrm{Cr}(\mathrm{VI})$ was determined by the DPC assay.

\section{ACTIVITY AND CHEMICAL ASSAYS}

Protein concentration was measured using the DC protein assay kit (Bio-Rad). Bovine serum albumin (Pierce) was used as a standard. All enzyme activity assays (nitrate, nitrite, and chromate reduction) were performed using the viologen-coupled reductase method (Stolz et al., 1997) with methyl or benzyl viologen. Ingel activity assays were performed using native gel electrophoresis to first separate proteins, prior to methyl viologen coupled activity assay analysis (Afkar et al., 2003). Protein electrophoresis was performed under non-denaturing conditions (the polyacrylamide gel contained $0.5 \%$ of CHAPS, the sample buffer contained $0.7 \%$ CHAPS and anode buffer $0.1 \%$ CHAPS) according to standard protocols. The in-gel assay was performed in $50 \mathrm{mM}$ Tris- $\mathrm{Cl}(\mathrm{pH}$ 7.9), with $10 \mathrm{mM}$ methyl viologen as the electron donor, and $\mathrm{KNO}_{3}$ $[0.1 \mathrm{M}], \mathrm{KNO}_{2}[10 \mathrm{mM}]$, or $\mathrm{K}_{2} \mathrm{CrO}_{4}[0.7 \mathrm{mM}]$ as the electron acceptors in presence of sodium dithionite. Images of the activity gels were documented using a densitometer (GS-800, Bio-Rad). After the activity assay was finished, gels were incubated for $15 \mathrm{~min}$ in $12.5 \%$ trichloroacetic acid (TCA) before staining with colloidal Coomassie stain.

Microscale solution assays were performed inside an inert atmosphere glove box (Vacuum Atmospheres) at $22^{\circ} \mathrm{C}$ using the ELx808 absorbance microplate reader (BioTek). The oxidation of methylviologen as a function of time was monitored at $630 \mathrm{~nm}$ and the data were analyzed using Gen5 Data Analysis Software (BioTek). The final reaction contained $3 \mathrm{mM}$ methyl viologen or benzyl viologen in $100 \mathrm{mM}$ Tris- $\mathrm{HCl}$ buffer at $\mathrm{pH}$ 7.6. A $60-\mathrm{mM}$ sodium dithionite stock solution was used to reduce the viologen reaction solution by titrating to a final absorbance of 1.2-1.6 at $630 \mathrm{~nm}$. All assay solutions were purged with nitrogen or argon gas for $20 \mathrm{~min}$, and then sealed before transfer into the anaerobic chamber. The enzyme was incubated with the reduced benzyl viologen for $10 \mathrm{~min}$ and the absorbance was monitored to ensure the rate of oxidation was insignificant prior to addition of substrate. The reaction was initiated by the addition of substrate (nitrate, chromate, or nitrite) and the absorbance was monitored until the reaction stopped. Under the given conditions, the rate of reduced benzyl viologen oxidation by the protein sample alone (i.e., no 
substrate) was found to be negligible. Activities were calculated as $\mu$ moles of viologen oxidized per min using the extinction coefficient of $13 \mathrm{mM}^{-1} \mathrm{~cm}^{-1}$ and $7.4 \mathrm{mM}^{-1} \mathrm{~cm}^{-1}$ for methyl- and benzyl-viologen, respectively (Jones and Garland, 1977). The rate of viologen oxidation was determined by plotting the concentration of reduced viologen over time (seconds). Linear regression (GraphPad Prism) of the initial data points (first $90 \mathrm{~s}$ after adding substrates) was used to calculate the rate of viologen oxidation.

Nitrite concentration was determined using the microtiter plate-based Griess assay (Borcherding et al., 2000). $\mathrm{KNO}_{3}$ (Fluka) was used as a standard for nitrite estimation, within the range of 1.6-100 $\mu \mathrm{M}$. Cr(VI) concentrations were determined using the DPC method (Saltzman, 1952). The standard reaction mixture contained $940 \mu \mathrm{L}$ sample, $50 \mu \mathrm{L} 3 \mathrm{M} \mathrm{H}_{2} \mathrm{SO}_{4}$, and $10 \mu \mathrm{L} 2.5 \% \mathrm{DPC}$ in acetone.

For selected samples, media were amended with $100 \mu \mathrm{M} \mathrm{Cr}$ (VI) and aliquots $(60 \mu \mathrm{L})$ were collected in $0,24,48,72,96$, and $120 \mathrm{~h}$. The samples were spiked with ${ }^{50} \mathrm{Cr}$ (III) and ${ }^{53} \mathrm{Cr}(\mathrm{VI})$ isotopes using isotope dilution mass spectrometry (MS) with EPA method 6800 on a Shimadzu ICP-MS (Kingston et al., 1998, 2005). Cr(VI) and Cr(III) concentrations were determined using Chromium Speciated Analysis Calculation Software (Applied Isotope Technologies, Inc.).

\section{PROTEINS PURIFICATION AND IDENTIFICATION}

Preparative CHAPS native-polyacrylamide gel electrophoresis (CN-PAGE) was used to separate proteins involved in nitrate reduction and $\mathrm{Cr}(\mathrm{VI})$. CN-PAGE was used to purify the multiheme cytochrome $\mathrm{c}$ from nitrate grown cultures of $\mathrm{G}$. metallireducens. A solid cylindrical (tube) gel, 2.5" diameter, was created by casting the gel inside a modified Model 491 PrepCell (Bio-Rad) as reported (Martínez Murillo et al., 1999). Briefly, the resolving and stacking gels contained $0.5 \%$ of CHAPS, the sample buffer contained $0.7 \%$ CHAPS, the anode buffer $0.1 \%$ CHAPS, and the cathode buffer contained no CHAPS. Electrophoresis was performed using cold buffer and separation was performed using $100 \mathrm{~V}$ for at least $3 \mathrm{~h}$. The entire tube gel was removed, washed with DI water, and then separated into small disk shaped sections, which were diced into $\sim 1 \mathrm{~cm}$ cubes prior to electroelution. Electroelution was conducted using the Elutrap ${ }^{\mathrm{TM}}$ System (Whatman) according to the manufacturer's guidelines. The diced gel samples were immersed in the CHAPS anode buffer. Electrophoresis was conducted at $100 \mathrm{~V}$ for $1 \mathrm{~h}$. SDS-PAGE was used to determine the relative molecular mass of the proteins, with a $4 \%$ acrylamide stacking gel and a $12 \%$ acrylamide resolving gel on a Mini-Protein gel system (Bio-Rad, Hercules, CA, USA). After colloidal coomassie blue staining, the gel was scanned with a Bio-Rad GS-800 densitometer and the molecular masses of the subunits calculated relative to the molecular weight standards (Quantity One, Bio-Rad). The electronic spectra for air-oxidized, dithionite reduced ( $13 \mathrm{mM} \mathrm{Na}_{2} \mathrm{~S}_{2} \mathrm{O}_{4}$ ), and chromate oxidized ( $3 \mathrm{mM} \mathrm{K}_{2} \mathrm{CrO}_{4}$ ) cytochrome was determined on a Cary 3 spectrophotometer.

Cells of S. barnesii were grown on $20 \mathrm{mM}$ nitrate and $15 \mathrm{mM}$ lactate medium in a New Brunswick Scientific Microferm anaerobic fermentor (14 L). Cells (9-13 g total) were harvested in the log phase of growth $(\sim 12 \mathrm{~h})$ and lysed by French Pressure Cell. Protease inhibitor cocktail (Sigma Chemical, St.
Louis, MO, USA) and DNAse were added to cold lysate immediately after lysis. The membrane fraction was obtained by ultracentrifugation $(100,000 \mathrm{~g})$. The membrane pellet was suspended in $50 \mathrm{mM}$ Tris-Cl buffer $\mathrm{pH} 7.7$, and then treated with detergent, either 3-[(3-Cholamidopropyl)dimethylammonio]1 -propanesulfonate (CHAPS) or $n$-octyl- $\beta$-D-glucopyranoside (OBGP) to solubilize membrane proteins. Insoluble proteins were removed by ultracentrifugation $(100,000 \mathrm{~g})$. The CHAPS soluble supernatant was subjected to subsequent ammonium sulfate precipitation (30\% saturation), and the supernatant was collected again via centrifugation $(50,000 \mathrm{~g}$ Beckman Coulter Ultracentrifuge) and then dialyzed to lower the salt concentration. The desalted fraction was loaded onto a DEAE anion exchange column and eluted with a $\mathrm{NaCl}$ gradient of $300 \mathrm{mM} \mathrm{NaCl}$ in $300 \mathrm{mM}$ Tris$\mathrm{HCl}$. A non-specific metalloid reductase, Rar, was solubilized from the membrane suspension with OBGP and enriched by subsequent ammonium sulfate precipitation. In-gel activity assays were done using CN-PAGE with the Mini-Protein gel system as described above.

Protein identification was made using in-gel trypsin digestion and Matrix Assisted Laser Desorption Time of Flight (MALDITOF) MS. Sample preparation for MALDI-TOF MS analysis was carried out using the methods described in Shevchenko et al. (2006). $\alpha$-Cyano-4-hydroxycinnamic acid (Fluka, Switzerland) was used to prepare the matrix solution at a concentration of $10 \mathrm{mg} / \mathrm{mL}$ in $70 \%$ acetonitrile/ $0.1 \%$ trifluoroacetic acid. The peptide solution $(0.5 \mu \mathrm{L})$ was deposited onto the MALDI target followed by $0.5 \mu \mathrm{L}$ of matrix solution. The MALDI-TOF MS was performed on a Voyager-DE STR MALDI-TOF mass spectrometer (Applied Biosystems, Foster City, CA, USA) in the reflector mode at the Genomics and Proteomics Core Lab of the University of Pittsburgh. External mass calibration was achieved utilizing calibration mixture 2 of the Sequazyme peptide mass standard kit (Applied Biosystems, Foster City, CA, USA). Proteins were identified from the NCBInr database by Mascot (http://www.matrixscience.com). Protein identities were assigned if the protein score was significant with stringency of $0.6 \mathrm{Da}$. Search parameters included carbamidomethylation of cysteine, possible oxidation of methionine, and one missed cleavage site.

\section{RESULTS}

\section{THE EFFECT OF CHROMATE ON BACTERIAL GROWTH}

All three organisms were grown with nitrate $(20 \mathrm{mM})$, as the terminal electron acceptor with either acetate ( $G$. metallireducens) or lactate ( $S$. barnesii and $D$. desulfuricans) as the electron donor and carbon source. Under these conditions all three organisms grew, with both G. metallireducens and D. desulfuricans reaching stationary phase later ( 4 and 2 days, respectively) than $S$. barnesii (1 day). From the optical density measurements (absorption at $600 \mathrm{~nm}), D$. desulfuricans cultures yielded two times larger cell mass that the other two organisms (OD's of $\sim 0.4$ in $D$. desulfuricans, and 0.2 in S. barnesii and G. metallireducens), even though similar inoculum volumes was used in all cases ( $S$. barnesii, D. desulfuricans, $3 \mathrm{~mL}$ of $48 \mathrm{~h}$ cultures, G. metallireducens, $3 \mathrm{~mL}$ of 5 day culture). Addition of chromate $(100 \mu \mathrm{M})$ to nitrate enriched media influenced the growth of all three organisms but differently (Figure 1). 

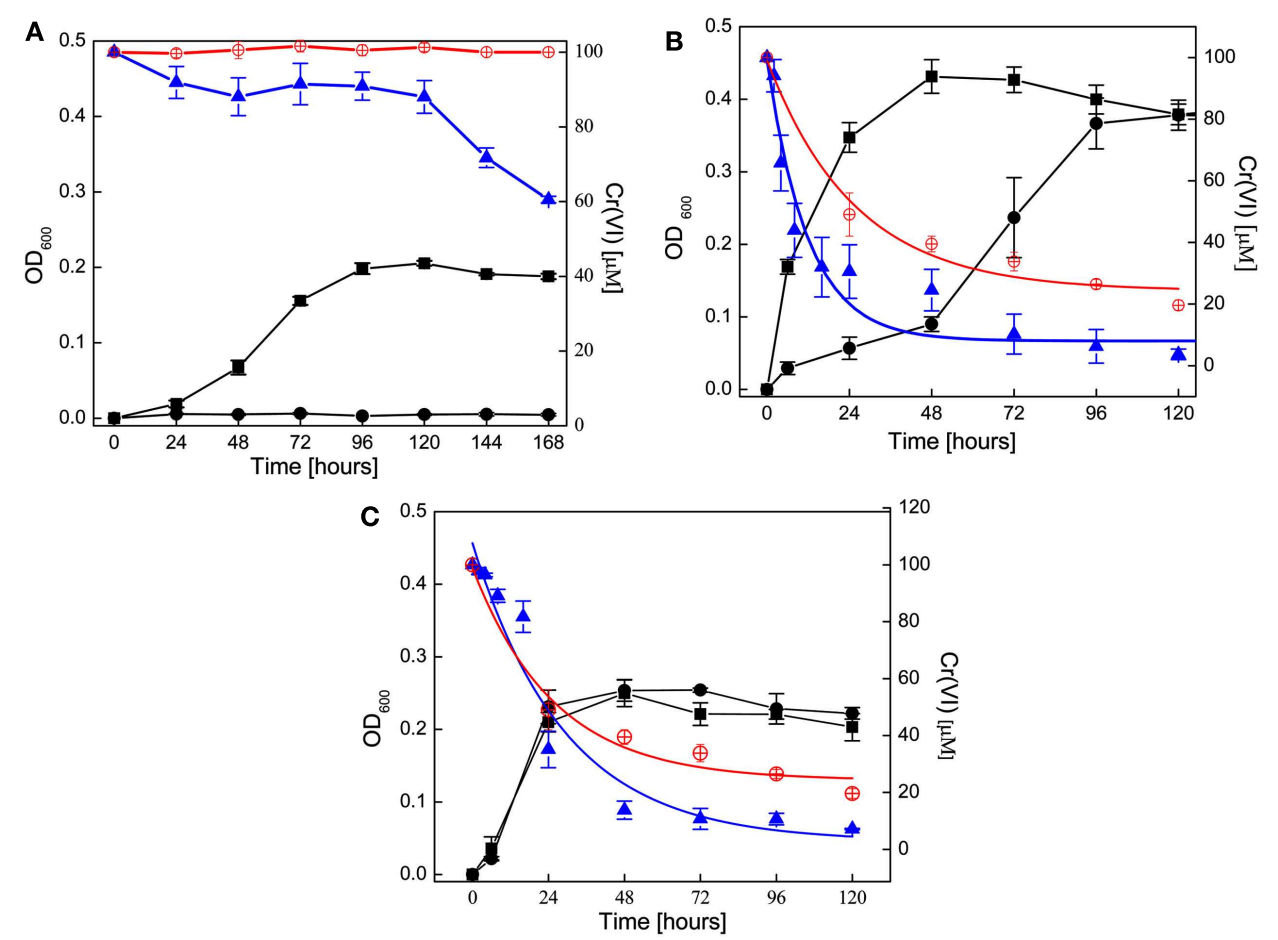

FIGURE 1 | Cell growth on nitrate in the presence of chromate (O) as compared to nitrate alone ( $\mathbf{a})$. G. metallireducens (A) was grown on FWA-NO $\mathrm{N}_{3}$ while D. desulfuricans (B), and S. barnesii (C) were grown on SES3 medium. Decrease in chromate concentration in living cultures is shown as $(\boldsymbol{\Delta})$. Chromium concentration in control experiments under abiotic conditions
(A) [FWA- $\mathrm{NO}_{3}$ medium (B,C), in SES3 medium without inoculum] is shown as $(\oplus)$. The rate of change in $\mathrm{Cr}(\mathrm{VI})$ concentration was computed by fitting with an exponential function, and the fitted curves are shown in $\mathbf{( B , C )}$ as spline traces. Detailed parameters are tabulated in the text. In each panel, the left axis represent the OD and chromate concentrations are shown on right axis.
G. metallireducens growth on nitrate was completely inhibited by the presence of $100 \mu \mathrm{M} \mathrm{Cr}$ (VI) for the duration of the experiment (168 h, Figure 1A), and no increase in cell density was detected. Interestingly, approximately $40 \%$ of $\mathrm{Cr}(\mathrm{VI})$ was transformed over the 7 day of incubation (Figure 1A) despite the lack of bacterial growth. In contrast, control experiments with uninoculated FWA- $\mathrm{NO}_{3}$ medium showed no significant reduction of chromium.

D. desulfuricans growth was altered by the presence of $\mathrm{Cr}(\mathrm{VI})$. $\mathrm{Cr}$ (VI) decreased the growth rate of $D$. desulfuricans by half, but did not affect the final growth yields (Figure 1B). During the prolonged lag phase $\mathrm{Cr}(\mathrm{VI})$ was rapidly reduced within the first $24 \mathrm{~h}$ and was below detection levels after 10 days (Figure 1B). Initially, there was no concomitant growth of cells and decrease in $\mathrm{Cr}(\mathrm{VI})$ concentration, but the culture was well into exponential growth phase by $72 \mathrm{~h}$. Thus it appeared that the concentration of $\mathrm{Cr}(\mathrm{VI})$ had to be reduced below $40 \mu \mathrm{M}$ before a robust respiratory growth on nitrate could begin (Figure 1B). A similar $\mathrm{Cr}$ (VI) induced lag phase has been seen in Desulfovibrio vulgaris when grown on sulfate (Klonowska et al., 2008). While uninoculated SES3 medium can also reduce chromate $(\sim 70 \%)$ over a period of $120 \mathrm{~h}$, the biotic reduction $\left(8.45 \times 10^{-2} \mathrm{~h}^{-1}\right)$ occurs at twice the abiotic rate $\left(3.89 \times 10^{-2} \mathrm{~h}^{-1}\right.$; Table 1$)$. Furthermore, when the experiments were repeated using $\mathrm{FWL}^{-\mathrm{NO}_{3}}$ medium, little abiotic $\mathrm{Cr}(\mathrm{VI})$ reduction was observed and the growth yields were comparable (Zhang, 2012).
S. barnesii exhibited little difference in growth kinetics or cell yield between cells grown on nitrate in the presence or absence of $\mathrm{Cr}(\mathrm{VI})$ (Figure 1C). The rate of $\mathrm{Cr}(\mathrm{VI})$ reduction also seemed to coincide with the increase in cell mass, with the $\mathrm{Cr}(\mathrm{VI})$ concentration leveling off at around $10 \mu \mathrm{M}$ as the cells went into stationary phase, suggesting that $S$. barnesii has an efficient cellular mechanism available for $\mathrm{Cr}(\mathrm{VI})$ transformation. It is interesting to note that in a previous study, S. barnesii was shown to concomitantly reduce selenate (in $\mu \mathrm{M}$ concentrations) while growing on nitrate (in $\mathrm{mM}$ concentrations) as the organism expressed both selenate and nitrate reductase enzymes (Oremland et al., 1999). Although the rate of change in $\mathrm{Cr}(\mathrm{VI})$ concentration reduction was significant in the inoculated media, S. barnesii cells were able to remove $\mathrm{Cr}(\mathrm{VI})$ more efficiently [S. barnesii decreased $\mathrm{Cr}(\mathrm{VI})$ concentration below $10 \mu \mathrm{M}$ within $48 \mathrm{~h}$, while the uninoculated media required $120 \mathrm{~h}$ to reach $10 \mu \mathrm{M}$. Figure shows $20 \mu \mathrm{M}$ ].

\section{CHROMATE REDUCTION IN LIVE CELLS, SPENT MEDIUM, AND WITH HEAT KILLED CELLS}

Initially, the chromium concentration was determined using the traditional DPC assay which is specific for $\mathrm{Cr}(\mathrm{VI})$. However, we also used isotope dilution ICP-MS, which can measure both $\mathrm{Cr}$ (III) and $\mathrm{Cr}(\mathrm{VI})$ to confirm that $\mathrm{Cr}(\mathrm{III})$ was formed and to validate the colorimetric DPC assay. Concentrations of $\mathrm{Cr}(\mathrm{VI})$ in the uninoculated $\mathrm{FWL}-\mathrm{NO}_{3}$ media were not significantly different among the ICP-MS and DPC methods. The ICP-MS measurements also 
Table 1 | Parameters obtained from non-linear curve fitting.

\begin{tabular}{|c|c|c|c|c|c|}
\hline \multirow[t]{2}{*}{ Organism/condition } & \multirow[t]{2}{*}{$R^{2}$} & \multicolumn{3}{|c|}{ Parameters } & \multirow[t]{2}{*}{ Rate/h } \\
\hline & & $y_{0}$ & $A_{1}$ & $t_{1}$ & \\
\hline D. desulfuricans in SES3 medium, live cells & 0.948 & $8.06( \pm 3.68)$ & $90.99( \pm 7.44)$ & $11.84( \pm 2.55)$ & $8.45 \times 10^{-2}$ \\
\hline D. desulfuricans in SES3 medium, heat killed & 0.995 & $4.18( \pm 0.92)$ & $95.65( \pm 2.64)$ & $1.14( \pm 0.10)$ & $87.72 \times 10^{-2}$ \\
\hline S. barnesii in SES3 medium, live cells & 0.952 & $2.85( \pm 8.51)$ & $104.73( \pm 9.26)$ & $29.09( \pm 8.10)$ & $3.44 \times 10^{-2}$ \\
\hline S. barnesii in SES3 medium, heat killed & 0.971 & $10.49( \pm 4.68)$ & $80.92( \pm 5.39)$ & $25.20( \pm 5.56)$ & $3.97 \times 10^{-2}$ \\
\hline SES3 medium only. Cr(VI) measurement by DPC method & 0.979 & $24.30( \pm 4.24)$ & $74.70( \pm 6.52)$ & $25.72( \pm 5.97)$ & $3.89 \times 10^{-2}$ \\
\hline SES3 medium only. Cr(VI) measurement by ICP-MS method & 0.955 & $28.08( \pm 4.94)$ & $69.27( \pm 8.81)$ & $19.79( \pm 6.95)$ & $5.05 \times 10^{-2}$ \\
\hline SES3 medium. Cr(III) measurement by ICP-MS method & 0.955 & $71.92( \pm 4.94)$ & $-69.27( \pm 8.81)$ & $-19.79( \pm 6.95)$ & $5.05 \times 10^{-2}$ \\
\hline
\end{tabular}

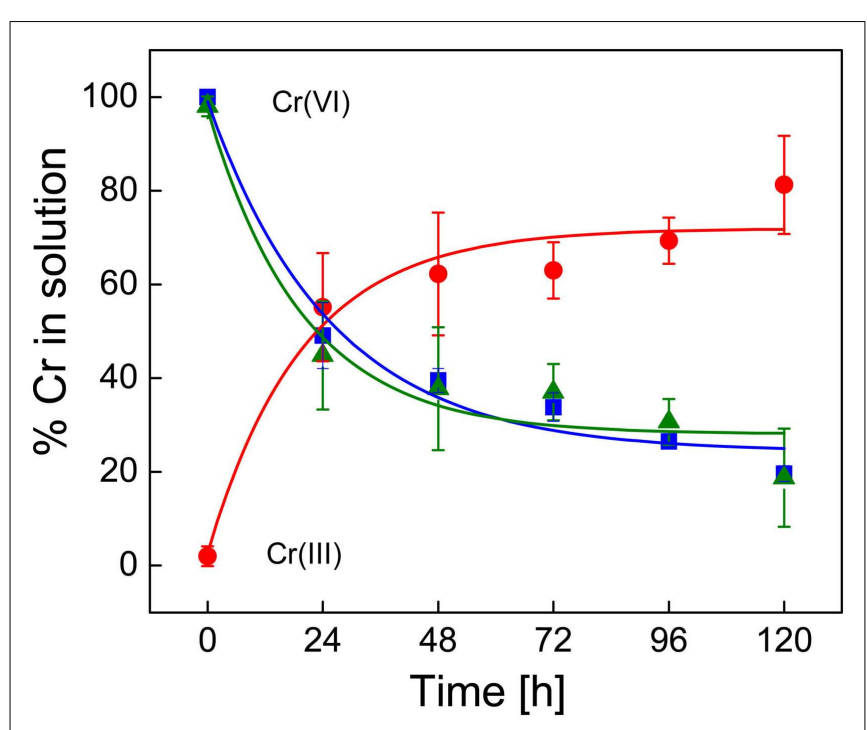

FIGURE 2 | Chromium(VI) reduction in uninoculated SES3 medium as determined by the diphenylcarbazide method ( $\square)$ for $\mathrm{Cr}(\mathrm{VI})$ and by the isotope dilution method with ICP-MS for $\mathrm{Cr}(\mathrm{VI})$ ( $\Delta$ ) and $\mathrm{Cr}(\mathrm{III})(\mathrm{O})$. Each of the measurements was done in triplicate with standard. The spline curves represent non-linear curve fitting.

demonstrated that $\mathrm{Cr}(\mathrm{VI})$ is stoichiometrically reduced to $\mathrm{Cr}$ (III) (Figure 2). The rate of increase $\left(5.3 \times 10^{-2} \mathrm{~h}^{-1}\right)$ in $\mathrm{Cr}$ (III) concentration was also comparable with that of the decrease in $\mathrm{Cr}(\mathrm{VI})$ concentration. Furthermore, the ICP-MS data also indicate that under the experimental conditions, results from the DPC assay and ICP-MS are comparable, as both analyses provided a $\mathrm{Cr}(\mathrm{VI})$ reduction rate of $5.9 \times 10^{-2} \mathrm{~h}^{-1}$ (assuming a first order process). Thus, kinetically, the data suggest that under the experimental conditions, $\mathrm{Cr}(\mathrm{VI})$ is reduced only to $\mathrm{Cr}(\mathrm{III})$, a process that requires three electrons. In all subsequent measurements the DPC method was used, and assumed that $\mathrm{Cr}(\mathrm{VI})$ was reduced to $\mathrm{Cr}(\mathrm{III})$ given the absence of precipitate in the spent culture medium.

Because G. metallireducens did not grow on nitrate media in the presence of $\mathrm{Cr}(\mathrm{VI})$ (Figure 1), the disappearance of $\mathrm{Cr}(\mathrm{VI})$ over time suggested the cells might still be able to reduce chromium. In order to investigate this possibility, cultures of G. metallireducens were grown on nitrate for $60 \mathrm{~h}$, then were exposed to $100 \mu \mathrm{M} \mathrm{Cr}(\mathrm{VI})$, and incubated for an additional $120 \mathrm{~h}$. Under



FIGURE 3 | Chromate reduction in cultures of $\boldsymbol{G}$. metallireducens and the filtered spent medium. The cells grown on nitrate for $60 \mathrm{~h}$ were exposed to $100 \mu \mathrm{M}$ chromate then incubated for $120 \mathrm{~h}$. Whole cells ( $\mathbf{\square}$ ) and filtered spent medium (๑).

these conditions, $\mathrm{Cr}(\mathrm{VI})$ was rapidly reduced by the cells to nondetectable levels by $24 \mathrm{~h}$ (Figure 3); however the cells could not continue to grow past $24 \mathrm{~h}$. To confirm that the bacteria are required for $\mathrm{Cr}(\mathrm{VI})$ reduction, the medium was filtered to remove live cells from the $60 \mathrm{~h}$ cultures and then exposed to $\mathrm{Cr}(\mathrm{VI})$. The spent medium showed little $\mathrm{Cr}(\mathrm{VI})$ reduction (Figure 3). These results indicate that live cells of $G$. metallireducens are required for $\mathrm{Cr}(\mathrm{VI})$ reduction, and that extracellular metabolites are not involved.

Chromate reduction was also examined in heat killed cells. Cells of $D$. desulfuricans and S. barnesii, grown on SES3 medium were harvested after $48 \mathrm{~h}$ of growth, then autoclaved and transferred to fresh media with amended $\mathrm{Cr}(\mathrm{VI})$ to examine chromate reduction activity by heat killed cells (Figure 4). For comparison, Figure 4 also shows the chromate reduction with medium only and with live cells. For S. barnesii cells, the rate of chromate reduction with the live cells is marginally faster than that with the medium only. The rate of chromate reduction with heat killed cells is comparable to that obtained with live bacteria. In contrast, the heat killed $D$. 

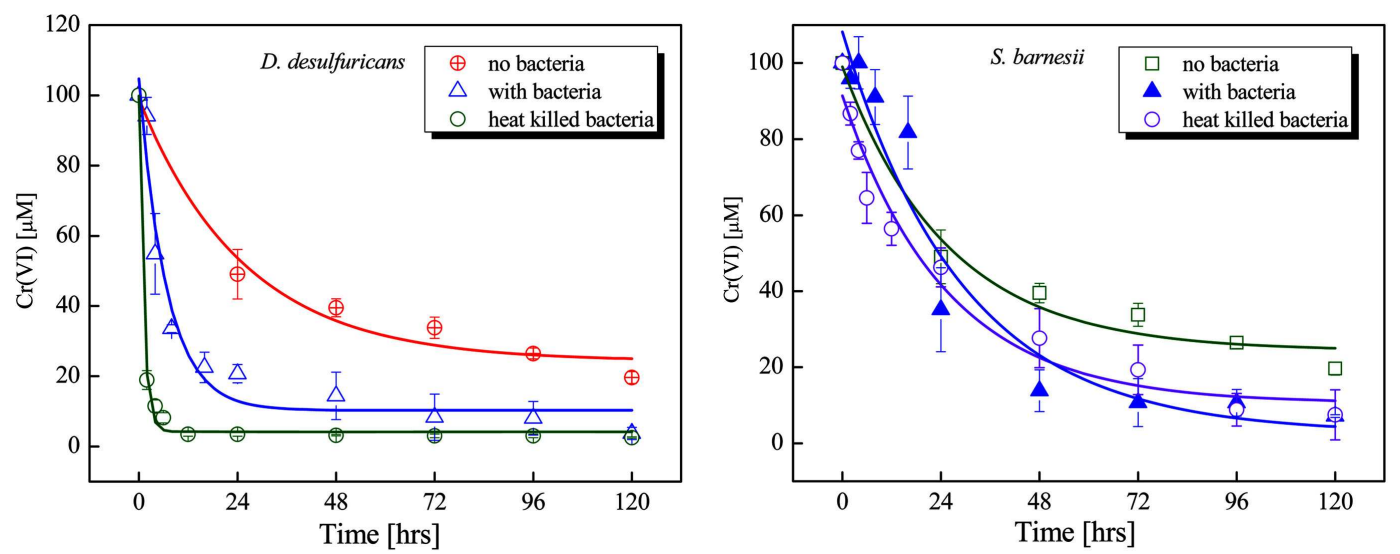

FIGURE 4 | Chromate reduction in cultures of $\boldsymbol{D}$. desulfuricans (left panel) and $\boldsymbol{S}$. barnesii (right panel) for live bacteria ( $\Delta$ ) and heat killed bacteria (O) as compared to the uninoculated SES3 medium ( $\oplus$ or $\square$ ). The spline curves are non-linear fit of the data from which the rate values were calculated.

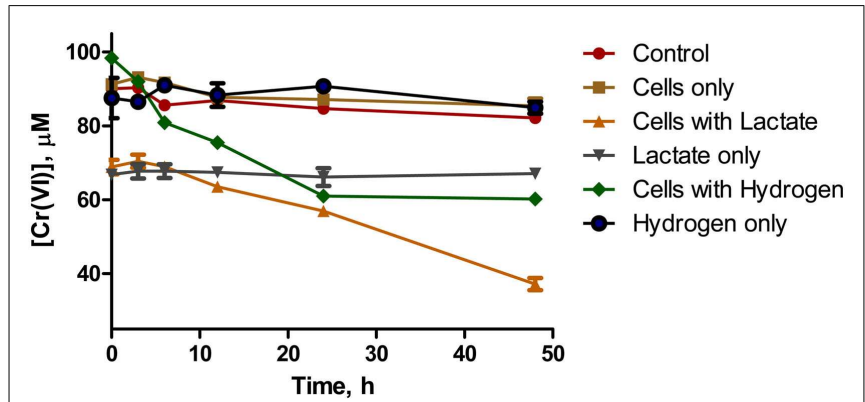

FIGURE 5 | Chromate reduction in whole cells of $\boldsymbol{D}$. desulfuricans provided with lactate $(\Delta)$ or hydrogen $(\downarrow)$ as electron donor. Controls were $\mathrm{Cr}(\mathrm{VI})$ with no cells or donor (O), $\mathrm{Cr}(\mathrm{VI})$ with cells only $(\boldsymbol{\square}), \mathrm{Cr}(\mathrm{VI})$ with lactate only and no cells $(\nabla), \mathrm{Cr}(\mathrm{VI})$ with hydrogen only and no cells

desulfuricans cells exhibit a much more rapid reduction of $\mathrm{Cr}(\mathrm{VI})$ (Table 1).

Whole cells of $D$. desulfuricans grown on nitrate showed little $\mathrm{Cr}(\mathrm{VI})$ reduction activity, even when provided a source of electron donor (e.g., lactate, $\mathrm{H}_{2} ;$ Figure 5). However, the filtered spent medium rapidly reduced $\mathrm{Cr}(\mathrm{VI})$ (Table 2). Caution was exercised as it was found that lactate alone (in the controls) reduced a certain amount (20-30\%) of Cr(VI) in solution. Nevertheless, autoclaved cultures (that contained both heat killed cells and spent medium) and autoclaved filtered spent medium exhibited greater rates of $\mathrm{Cr}(\mathrm{VI})$ reduction indicating that this activity was enhanced by heating (Table 2). In addition, this activity was concentration dependent as demonstrated by serial dilution (Zhang, 2012). These results indicate that although viable cells do possess the ability to reduce $\mathrm{Cr}(\mathrm{VI})$, in culture, the main mechanism of resistance is through a heat stable secreted metabolite. Ongoing studies from our laboratories will further elucidate this point.

Both S. barnesii cells grown on nitrate and the filtered spent medium could reduce $\mathrm{Cr}(\mathrm{VI})$. Similar to the results seen for $D$. desulfuricans strain 27774, autoclaved cultures, and filtered spent medium alone showed this activity to be enhanced after heating
Table 2 | Chromate reduction activity in spent medium of nitrate grown cultures of $D$. desulfuricans.

\begin{tabular}{llll}
\hline Time(h)/Cr(VI) $(\boldsymbol{\mu M})$ & HKC & HK-FSM & FSM \\
\hline 0 & 100 & 100 & 100 \\
2 & 5.51 & 4.08 & 19.4 \\
6 & 0 & 0 & 4.48 \\
12 & 0 & 0 & 4.02 \\
24 & 0 & 0 & 0 \\
48 & 0 & 0 & 0
\end{tabular}

The average from four independent experiments is shown. HKC - heat killed lautoclaved) culture, FSM - filtered spent medium, HK-FSM - heat killed (autoclaved) filtered spent medium.

Table 3 | Chromate reduction activity in spent medium of nitrate grown cultures of $S$. barnesii.

\begin{tabular}{llll}
\hline Time(h)/Cr(VI) $(\boldsymbol{\mu M})$ & HKC & HK-FSM & FSM \\
\hline 0 & 100 & 100 & 100 \\
2 & 57.33 & 47.56 & 64.49 \\
6 & 54.67 & 37.80 & 62.31 \\
12 & 32.0 & 25.61 & 61.59 \\
24 & 8.0 & 11.83 & 42.03 \\
48 & 0 & 4.88 & 26.81 \\
\hline
\end{tabular}

The average from four independent experiments is shown. HKC-heat killed (autoclaved) culture, FSM - filtered spent medium, HK-FSM - heat killed (autoclaved) filtered spent medium.

(Table 3). Thus S. barnesii chromate reduction appears to be both cell associated and extracellular.

\section{CHROMIUM REDUCTION BY PROTEIN FRACTIONS}

To determine whether $\mathrm{Cr}(\mathrm{VI})$ was inhibiting growth though the inhibition of nitrate and/or nitrite reductase enzymes, we examined the nitrate and nitrite reductase activity with cell fractions 
and purified proteins. Both nitrate and nitrite reductase activities were affected by the presence of $\mathrm{Cr}(\mathrm{VI})$, with nitrite reductase activity inhibited to varying extents in all three organisms. Dissimilatory sulfite reductase ( $\mathrm{dSiR})$, which can reduce nitrite, was enriched from cells of $D$. desulfuricans grown on nitrate (Lui et al., 1994). We found that dSiR nitrite reduction was inhibited $(\sim 40 \%$ reduction) by the presence of $\mathrm{Cr}$ (VI). No direct chromate reduction was detected in any protein fractions, suggesting that $\mathrm{Cr}(\mathrm{VI})$ reduction in $D$. desulfuricans is not enzyme catalyzed. The rate of nitrite reduction in cell lysates of G. metallireducens in the presence of $\mathrm{Cr}(\mathrm{VI})$ was least affected, with only a $10 \%$ decrease in activity as compared to nitrite alone. In the process of purifying components of the DNRA pathway from G. metallireducens grown on nitrate, a multiheme c-type cytochrome that exhibited nitrite reductase activity was isolated. A prominent pink band that separated in preparative gels was found to contain two proteins of relative molecular masses of 34 and $9 \mathrm{kDa}$ respectively (Figure 6). The larger protein was identified by MALDI-TOF to be annotated as the hypothetical protein Gmet_0913 (accession number 78222133). The sequence was found to contain nine heme-c binding $(\mathrm{CXXCH})$ motifs. The electronic spectrum was also consistent with a c-type cytochrome with absorbance maxima at 408, 522, and $551 \mathrm{~nm}$ for the dithionite reduced protein (Figure 6). In addition, the dithionite reduced cytochrome could be oxidized with nitrite or $\mathrm{Cr}(\mathrm{VI})$. Furthermore, nitrite reductase activity as measured using the methyl viologen assay indicated the activity was affected by chromate $(0.7 \mathrm{mM})$. Future research with isolated enzymes to establish the significance of this enzyme in nitrite reduction is planned.

For S. barnesii, the effect of $\mathrm{Cr}(\mathrm{VI})$ on nitrate and nitrite reductase activity was dependent on whether the cells had been exposed to $\mathrm{Cr}(\mathrm{VI})$ during growth. Cell lysates from cells grown on nitrate and $\mathrm{Cr}(\mathrm{VI})$ exhibited less activity than the cells grown on nitrate alone. Interestingly, when chromate was added to the reaction mixture, nitrate reductase activity was higher in cells grown on nitrate alone while $\mathrm{Cr}(\mathrm{VI})$ had no effect on nitrate reductase activity in cells grown on nitrate and chromate (Figure 7). Conversely, nitrite reductase activity was greater $(47 \%)$ in cell lysates of cultures grown on nitrate in the presence of $\mathrm{Cr}(\mathrm{VI})$ than those grown on nitrate alone (Figure 8). Nitrite reductase activity was inhibited, however, by the presence of $\mathrm{Cr}(\mathrm{VI})$ in the reaction mixture regardless of whether the cells had been grown in the presence or absence of $\mathrm{Cr}(\mathrm{VI})$. Lastly, cell lysates of S. barnesii could reduce $\mathrm{Cr}(\mathrm{VI})$ (Figure 9) as evidenced by the rapid (within $200 \mathrm{~s}$ ) and complete oxidation of reduced benzyl viologen. These data suggest that chromate can be enzymatically reduced by $S$. barnesii.

In order to further elucidate the cellular mechanism for $\mathrm{Cr}$ (VI) reduction by $S$. barnesii, solubilized membrane proteins were subjected to both CN-PAGE activity assays and sequential ammonium sulfate precipitation followed by DEAE ion chromatography. Ingel activity assays indicated that two different protein bands could couple methyl viologen oxidation to nitrite reduction as these proteins were clearly separated on the native gel (Figure 10). A non-specific redox active protein, Rar, was subsequently identified by MALDI-TOF MS of the excised lower active band after purification to homogeneity in a second dimension SDS-PAGE (Figures 10B,C). Rar could be solubilized with the detergent OBGP and highly enriched fractions could be obtained with subsequent ammonium sulfate precipitation as it remained soluble at $75 \%$ saturation (Sparacino-Watkins, 2011). In addition to a nitrite and variety of metalloids (e.g., selenate, selenite, arsenate) as had been previously determined (Stolz and Oremland, 1999), in-gel assays indicated that Rar could also couple the oxidation of methyl viologen to the reduction of $\mathrm{Cr}(\mathrm{VI})$ (Sparacino-Watkins, 2011).



FIGURE 6 |The multiheme cytochrome c annotated as hypothetical protein Gmet_0913 from G. metallireducens. Left panel, SDS-PAGE (G3 refers to fraction G3 of the preparatory electrophoresis). Right panel, the UVNis electronic spectra of fraction G3, showing the as-isolated (grey line) and the dithionite reduced spectrum (black line). 


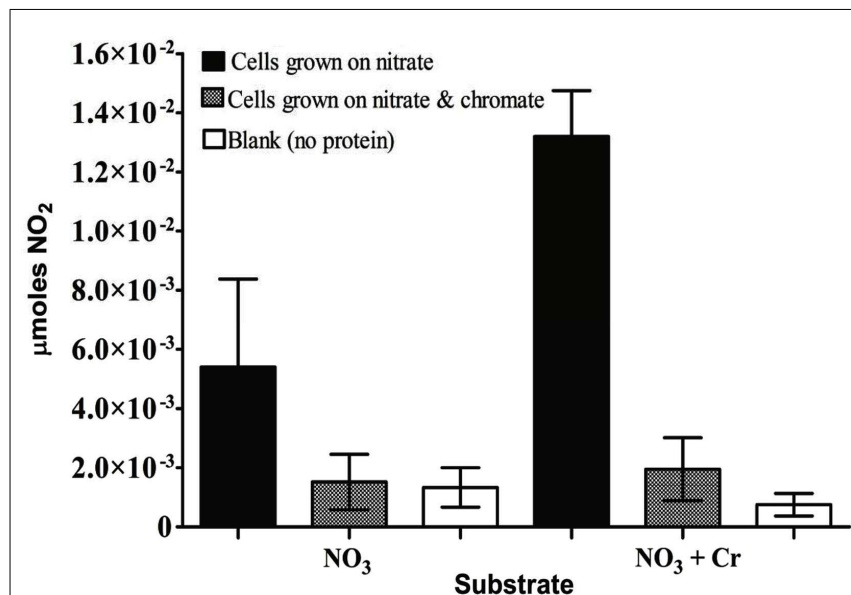

FIGURE 7 | The effect of chromate on nitrate reductase activity in $\boldsymbol{S}$. barnesii cell lysates. The activity was determined for lysates prepared from cells grown on nitrate medium alone (black bars) or amended with chromate (gray bars). The blank (white bars) contained the reaction mixture without protein.



FIGURE 8 | The effect of chromate on the nitrite reductase activity in $\boldsymbol{S}$. barnesii cell lysates. The activity was determined for lysates prepared from cells grown on nitrate medium alone (black bars) or amended with chromate (gray bars). The blank (white bars) contained the reaction mixture without protein.

\section{DISCUSSION}

The growth experiments clearly showed that under nitrate respiring conditions, the three organisms responded differently. We had originally hypothesized that $\mathrm{Cr}(\mathrm{VI})$ reduction by G. metallireducens would not occur under dissimilatory nitrate reducing conditions, as nitrate reduction via Nar is more thermodynamically favorable than $\mathrm{Cr}(\mathrm{VI})$ reduction (Stolz et al., 1999; Ackerley et al., 2004). Instead, the cells could not grow in the presence of $\mathrm{Cr}(\mathrm{VI})$. Nevertheless, $\mathrm{Cr}(\mathrm{VI})$ was slowly reduced over time in these cultures. The results that whole cells, but not filtered spent medium, could reduce $\mathrm{Cr}(\mathrm{VI})$ suggests that G. metallireducens utilizes a cell associated mechanism for $\mathrm{Cr}(\mathrm{VI})$ reduction but cannot efficiently detoxify $\mathrm{Cr}(\mathrm{VI})$ for normal growth.



FIGURE 9 |The oxidation of reduced benzyl viologen by $\boldsymbol{S}$. barnesii lysate in the presence of chromate.

Previous investigations of nitrate respiration in G. metallireducens revealed that a low potential cytochrome, putatively identified as Nrf, could be oxidized by Cr(VI) (Lin, 1994; Martínez Murillo et al., 1999). This work here revealed an additional candidate c-type cytochrome, Gmet_0913, that not only could couple nitrite reduction to methyl viologen oxidation, but was also oxidized by $\mathrm{Cr}(\mathrm{VI})$. Thus, it is plausible that $\mathrm{Cr}(\mathrm{VI})$ can inhibit the DNRA pathway by oxidizing cytochromes, like Nrf. Our future studies will investigate the effect of $\mathrm{Cr}(\mathrm{VI})$ of nitrite reduction with the isolated enzymes, as it is not clear if cytochrome c oxidation by $\mathrm{Cr}(\mathrm{VI})$ produced $\mathrm{Cr}(\mathrm{III})$. A second plausible source of the $\mathrm{Cr}$ (VI) reduction in G. metallireducens may be chemotaxis and motility proteins. It is also possible that the conductive pili may be involved in $\mathrm{Cr}(\mathrm{VI})$ reduction. We have found that chemotaxis and motility proteins are up-regulated in chromate exposed cells (Basu et al., 2010; Chovanec et al., 2010). A similar mechanism has been reported for Enterobacter cloacae (Yang et al., 2007). An alternative mechanism is that $\mathrm{Cr}(\mathrm{VI})$ is reduced by $\mathrm{Fe}(\mathrm{II})$ produced through dissimilatory iron reduction. $\mathrm{Cr}(\mathrm{VI})$ reduction by $\mathrm{Fe}(\mathrm{II})$ is well established (Kamaludeen et al., 2003; Cheng et al., 2010; Xu et al., 2012). Amending the FWA- $\mathrm{NO}_{3}$ medium with ferric citrate did indeed result in the reduction of $\mathrm{Cr}(\mathrm{VI})$ however, whether the process is abiotic or biologically induced remains to be determined.

The growth experiments with $D$. desulfuricans showed that $\mathrm{Cr}(\mathrm{VI})$ initially inhibits growth on nitrate, but that growth can commence after a short lag phase. Once the $\mathrm{Cr}(\mathrm{VI})$ concentration fell below $40 \mu \mathrm{M}$, exponential growth began. Interestingly, whole washed cells showed little $\mathrm{Cr}(\mathrm{VI})$ reduction activity, whether an exogenous electron donor such as hydrogen or acetate was provided. Most of the activity was in the filtered spent medium. Investigation into possible enzymatic origins for this activity indicated that $\mathrm{Cr}$ (VI) does inhibit nitrite reduction by enriched protein fractions, such as the dSiR enzyme. Furthermore, that $\mathrm{Cr}(\mathrm{VI})$ could oxidize dSiR, suggests that $\mathrm{Cr}(\mathrm{VI})$ may act non-specifically by oxidizing redox active proteins, thus altering the redox poise and inducing oxidative stress, similar to what was observed in $G$. 


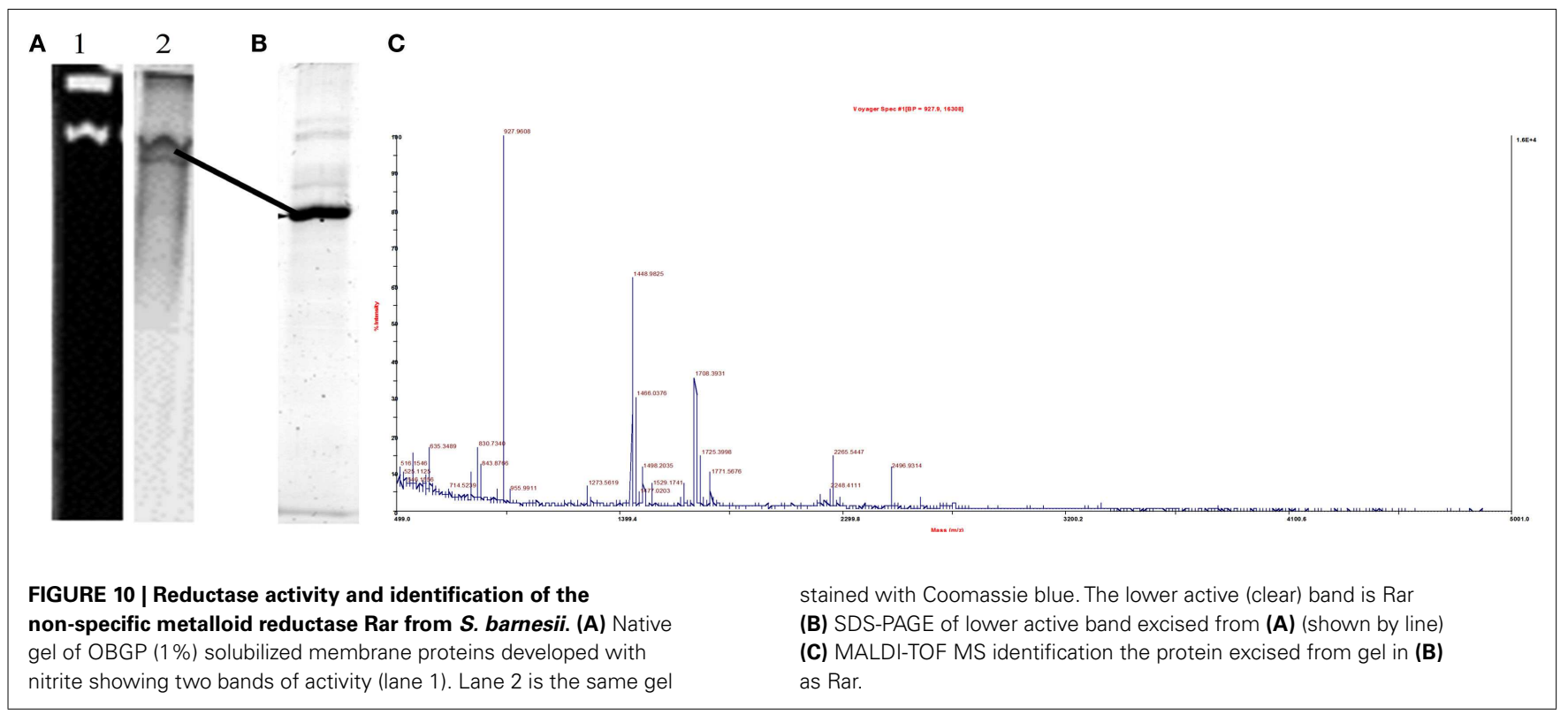

metallireducens. A search of the annotated genome of D. desulfuricans strain ATCC 27774 revealed that it does possess a homolog of [NiFe] hydrogenases that have been shown to reduce $\mathrm{Cr}(\mathrm{VI})$ in other organisms. In addition, our results using hydrogen as the electron donor (Figure 5) indicate that the amount of $\mathrm{Cr}(\mathrm{VI})$ reduced by hydrogenase is relatively small. Thus, the bulk of $\mathrm{Cr}(\mathrm{VI})$ reduction is not enzymatic, but rather appears to be mediated by a heat stable, redox active secondary metabolite secreted into the medium.

From the $S$. barnesii growth experiments we found that this organism can simultaneously reduce $\mathrm{Cr}(\mathrm{VI})$ while respiring nitrate. The enzyme assays indicate that $S$. barnesii cell lysate can reduce $\mathrm{Cr}(\mathrm{VI})$, as demonstrated by the viologen-coupled reductase assay. Also, it appears that the presence of chromate in the growth medium can actually increase nitrite reduction by $S$. barnesii cell lysates, compared to cells grown on nitrate alone. Still nitrite reduction is inhibited by the presence of $\mathrm{Cr}(\mathrm{VI})$ in the assay, independent of the growth conditions [with or without $\mathrm{Cr}(\mathrm{VI})$ in the media]. This result lead us to suggest that the living cells have a mechanism to detoxify $\mathrm{Cr}(\mathrm{VI})$, presumably protecting the sensitive redox active proteins like Nrf from oxidative stress, as lysing the cells makes the enzymes more sensitive to $\mathrm{Cr}(\mathrm{VI})$. Thus physiologically there must be a separate mechanism for $\mathrm{Cr}(\mathrm{VI})$ reduction such as Rar (vide infra).

In-gel activity assays revealed that Rar can couple methyl viologen oxidation to chromate reduction. While the Rar catalyzed chromate reduction was not present in the liquid protein assays, it is a potential source of the activity seen in whole washed cells. In addition, assays with filtered spent medium indicate that redox active secondary metabolites are also secreted into the medium. Thus the combination of the secreted metabolite and the presence of a non-specific metalloid reductase (Rar) may provide resistance to $\mathrm{Cr}(\mathrm{VI})$ allowing the components of nitrate respiration (e.g., Nap, Nrf) to continue to function.

\section{CONCLUSION}

This investigation demonstrates that each organism, G. metallireducens, D. desulfuricans, and S. barnesii, reacts differently to chromate in the presence of nitrate. G. metallireducens and D. desulfuricans appear to co-metabolize $\mathrm{Cr}(\mathrm{VI})$ reduction while utilizing DNRA to fuel growth, yet each organism utilizes different molecular mechanism of chromate reduction. Our results suggest that $\mathrm{Cr}(\mathrm{VI})$ can influence the activity of the enzymes involved in DNRA, however, the exact nature is yet to be fully understood. Cytochromes, including the multiheme nitrite reductase (Nrf), can be readily oxidized by $\mathrm{Cr}(\mathrm{VI})$ thus rendering them inoperable. Providing an exogenous of source of reducing equivalents could help maintain cellular redox poise and enhance the rates of $\mathrm{Cr}(\mathrm{VI})$ reduction. Our results also demonstrated that each of these model organisms has a unique mechanism for $\mathrm{Cr}(\mathrm{VI})$ amelioration. In culture, G. metallireducens appears to reduce $\mathrm{Cr}(\mathrm{VI})$ either indirectly through the production of $\mathrm{Fe}(\mathrm{II})$ or by direct cell contact, perhaps through conductive pili. In nature, the elevated concentrations of iron associated with environments where Geobacter species are typically found allow for $\mathrm{Cr}(\mathrm{VI})$ reduction by biologically produced $\mathrm{Fe}(\mathrm{II})$. We suggest that $D$. desulfuricans, $\mathrm{Cr}(\mathrm{VI})$ reduction and resistance involves a heat stabile and readily soluble secreted metabolite; direct cell contact is not required. The identity of this compound and the nature of its reactivity toward $\mathrm{Cr}(\mathrm{VI})$ remain to be resolved. Lastly, S. barnesii is highly resistant to $\mathrm{Cr}(\mathrm{VI})$ as it possesses both a cell associated reductase and a redox active secreted metabolite. The ability to simultaneously reduce $\mathrm{Cr}(\mathrm{VI})$ and other metals and metalloids (e.g., selenium) while growing by nitrate respiration suggests this organism may be useful in remediation strategies involving natural attenuation. To this extent it is encouraging to note that Sulfurospirillum species have indeed been detected at $\mathrm{Cr}(\mathrm{VI})$ contaminated sites. Further studies on chromium metabolism in all three organisms will be greatly enhanced by proteomic investigations facilitated by the availability of genomic data, investigations currently underway. 


\section{ACKNOWLEDGMENTS}

The authors would like to thank D. Lovley for the culture of Geobacter metallireducens, and H. M. S. Kingston for assistance in

\section{REFERENCES}

Ackerley, D. F., Gonzalez, C. F., Park, C. H., Blake, R. II, Keyhan, M., and Matin, A. (2004). Chromate-reducing properties of soluble flavoproteins from Pseudomonas putida and Escherichia coli. Appl. Environ. Microbiol. 70, 873-882.

Afkar, E., Lisak, J., Saltikov, C., Basu, P., Oremland, R. S., and Stolz, J. F. (2003). The respiratory arsenate reductase from Bacillus selenitireducens strain MLS10. FEMS Microbiol. Lett. 226, 107-112.

Arias, Y. M., and Tebo, B. M. (2003). $\mathrm{Cr}(\mathrm{VI})$ reduction by sulfidogenic and nonsulfidogenic microbial consortia. Appl. Environ. Microbiol. 69, 1847-1853.

Ball, J. W., and Nordstrom, D. K. (1998). Critical evaluation and selection of standard state thermodynamic properties for chromium metal and its aqueous ions, hydrolysis species, oxides, and hydroxides. J. Chem. Eng. Data 43, 895-918.

Basu, P., Chovanec, P., SparacinoWatkins, C., Stolz, J. F., and Bhat, V. (2010). "The effect of chromium on the proteome of Geobacter metallireducens," in 58th ASMS Conference on Mass Spectrometry and Allied Topics, Salt Lake City.

Battaglia-Brunet, F., Foucher, S., Denamur, A., Ignatiadis, I., Michel, C., and Morin, D. (2002). Reduction of chromate by fixed films of sulfatereducing bacteria using hydrogen as an electron source. J. Ind. Microbiol. Biotechnol. 28, 154-159.

Borcherding, H., Leikefeld, S., Frey, C., Diekmann, S., and Steinruecke, P. (2000). Enzymatic microtiter platebased nitrate detection in environmental and medical analysis. Anal. Biochem. 282, 1-9.

Branco, R., Chung, A. P., Johnston, T., Gurel, V., Morais, P., and Zhitkovich, A. (2008). The chromate-inducible chrBACF operon from the transposable element TnOtChr confers resistance to chromium(VI) and superoxide. J. Bacteriol. 190, 6996-7003.

Bruschi, M., Bertrand, P., More, C., Leroy, G., Bonicel, J., Haladjian, J., et al. (1992). Biochemical and spectroscopic characterization of the high molecular weight cytochrome c from Desulfovibrio vulgaris Hildenborough expressed in Desulfovibrio desulfuricans G200. Biochemistry 31, 3281-3288.
Camargo, F. A., Bento, F. M., Okeke, B. C., and Frankenberger, W. T. (2003a). Chromate reduction by chromium-resistant bacteria isolated from soils contaminated with dichromate. J. Environ. Qual. 32, 1228-1233.

Camargo, F. A., Okeke, B. C., Bento, (2003b). In vitro reduction of hexavalent chromium by a cell-free extract of Bacillus sp. ES 29 stimulated by Cu2. Appl. Microbiol. Biotechnol. 62, 569-573.

Chardin, B., Giudici-Orticoni, M. T., De Luca, G., Guigliarelli, B., and Bruschi, M. (2003). Hydrogenases in sulfate-reducing bacteria function as chromium reductase. Appl. Microbiol. Biotechnol. 63, 315-321.

Cheng, Y., Yan, F., Huang, F., Chu, W., Pan, D., Chen, Z., et al. (2010). Bioremediation of $\mathrm{Cr}(\mathrm{VI})$ and immobilization as $\mathrm{Cr}$ (III) by Ochrobactrum anthropi. Environ. Sci. Technol. 44, 6357-6363.

Cheung, K. H., and Gu, J. D. (2003). Reduction of chromate (CrO4(2)) by an enrichment consortium reducing bacteria. Chemosphere 52, 1523-1529.

Chovanec, P., Sparacino-Watkins, C., Basu, P., and Stolz, J. F. (2010). "Proteome changes induced by chromate exposure in Geobacter metallireducens," in American Society for Microbiology General Meeting, San Diego.

Cox, P. A. (1995). The Elements on Earth. Oxford: Oxford University Press.

Czjzek, M., Guerlesquin, F., Bruschi, M., and Haser, R. (1996). Crystal structure of a dimeric octaheme cytochrome c3 (M(r) 26,000) from Desulfovibrio desulfuricans Norway. Structure 4, 395-404.

Jones, R. W., and Garland, P. B. (1977). Sites and specificity of the reaction of bipyridylium compounds with anaerobic respiratory enzymes of Escherichia coli. Effects of permeability barriers imposed by the cytoplasmic membrane. Biochem. J. 164, 199-211.

Kamaludeen, S. P. B., Megharaj, M., Juhasz, A. L., Sethunathan, N., and Naidu, R. (2003). Chromiummicroorganism interactions in soils: remediation implications. Rev. Environ. Contam. Toxicol. 178, 93-164. F. M., and Frankenberger, W. T. and an isolate of marine sulfate- the ICP-MS analysis. This work was funded by the DOE Environmental Remediation Science Program grant number DE-FG027ER64372.

Kanmani, P., Aravind, J., and Preston, D. (2012). Remediation of chromium contaminants using bacteria. Int. J. Environ. Sci. Technol. (Tehran) 9, 183-193.

Kingston, H. M., Cain, R., Huo, D., and Rahman, G. M. M. (2005). Determination and evaluation of hexavalent chromium in power plant coal combustion by-products and costeffective environmental remediation solutions using acid mine drainage. J. Environ. Monit. 7, 899-905.

Kingston, H. M., Huo, D., Lu, Y. and Chalk, S. (1998). Accuracy in species analysis: speciated isotope dilution mass spectrometry (SIDMS) exemplified by the evaluation of chromium species. Spectrochim. Acta B At. Spectrosc. 53B, 299-309.

Klonowska, A., Clark, M., Thieman, S., Giles, B., Wall, J., and Fields, M. (2008). Hexavalent chromium reduction in Desulfovibrio vulgaris Hildenborough causes transitory inhibition of sulfate reduction and cell growth. Appl. Microbiol. Biotechnol. 78, 1007-1016.

Kwak, Y. H., Lee, D. S., and Kim, H. B. (2003). Vibrio harveyi nitroreductase is also a chromate reductase. Appl. Environ. Microbiol. 69, 4390-4395.

Lin, W. (1994). The purification and characterization of the $46 \mathrm{kDa} \mathrm{c}$ type cytochrome from Geobacter metallireducens strain GS-15. MS thesis, Duquesne University, Pittsburgh.

Liu, M. C., and Peck, H. D. Jr. (1981). The isolation of a hexaheme cytochrome from Desulfovibrio desulfuricans and its identification as a new type of nitrite reductase. J. Biol. Chem. 256, 13159-13164.

Losi, M. E., Amrhein, C., and Frankenberger, W. T. Jr. (1994). Environmental biochemistry of chromium. Rev. Environ. Contam. Toxicol. 136, 91-121.

Lovley, D. R., Giovannoni, S. J., White, D. C., Champine, J. E., Phillips, E. J., Gorby, Y. A., et al. (1993). Geobacter metallireducens gen. nov. sp. nov., a microorganism capable of coupling the complete oxidation of organic compounds to the reduction of iron and other metals. Arch. Microbiol. 159, 336-344.

Lovley, D. R., and Phillips, E. J. (1988). Novel mode of microbial energy metabolism: organic carbon oxidation coupled to dissimilatory reduction or iron or manganese. Appl. Environ. Microbiol. 54, 1472-1480.

Lovley, D. R., and Phillips, E. J. P. (1994). Reduction of chromate by Desulfovibrio vulgaris and its c3 cytochrome. Appl. Environ. Microbiol. 60, 726-728.

Lui, S. M., Liang, W., Soriano, A., and Cowan, J. A. (1994). Enzymic reduction of inorganic anions. Variabletemperature steady-state and presteady-state kinetics experiments to map the energy profile of an enzymic multielectron redox reaction. Application to the dissimilatory sulfite reductase from Desulfovibrio vulgaris (Hildenborough). J. Am. Chem. Soc. 116, 4531-4536.

Marietou, A., Richardson, D., Cole, J., and Mohan, S. (2005). Nitrate reduction by Desulfovibrio desulfuricans: a periplasmic nitrate reductase system that lacks NapB, but includes a unique tetraheme c-type cytochrome, NapM. FEMS Microbiol. Lett. 248, 217-225.

Martínez Murillo, F., Gugliuzza, T., Senko, J., Basu, P., and Stolz, J. F. (1999). A heme-C-containing enzyme complex that exhibits nitrate and nitrite reductase activity from the dissimilatory iron-reducing bacterium Geobacter metallireducens. Arch. Microbiol. 172, 313-320.

McLean, J., and Beveridge, T. J. pseudomonad isolated from a site contaminated with chromated copper arsenate. Appl. Environ. Microbiol. 67, 1076-1084.

Mehta, N. J., and Vaidya, V. K. (2010). Application of chromium resistant organisms in bioremediation. J. Ind. Pollut. Control Pap. 26, 23-29.

Michel, C., Brugna, M., Aubert, C., Bernadac, A., and Bruschi, M. (2001). Enzymatic reduction of chromate: comparative studies using sulfate-reducing bacteria. Key role of polyheme cytochromes $\mathrm{c}$ and hydrogenases. Appl. Microbiol. Biotechnol. 55, 95-100.

Moore, M. D., and Kaplan, S. (1992). Identification of intrinsic high-level resistance to rare-earth oxides and oxyanions in members of the class tellurite, selenite, and rhodium sesquioxide reduction in Rhodobacter sphaeroides. J. Bacteriol. 174, 1505-1514. (2001). Chromate reduction by a Proteobacteria: characterization of 
Moore, M. D., and Kaplan, S. (1994). Members of the family Rhodospirillaceae reduce heavy-metal oxyanions to maintain redox poise during photosynthetic growth. ASM News 60, 17-23.

Morales, D. K., Ocampo, W., and Zambrano, M. M. (2007). Efficient removal of hexavalent chromium by a tolerant Streptomyces sp. affected by the toxic effect of metal exposure. J. Appl. Microbiol. 103, 2704-2712.

Nepple, B. B., Kessi, J., and Bachofen, R. (2000). Chromate reduction in the phototrophic bacterium Rhodobacter sphaeroides. J. Ind. Microbiol. Biotechnol. 25, 198-203.

Nies, D. H., and Silver, S. (1995). Ion efflux systems involved in bacterial metal resistances. J. Ind. Microbiol. 14, 186-199.

Oremland, R. S., Blum, J. S., Bindi, A. B., Dowdle, P. R., Herbel, M., and Stolz, J. F. (1999). Simultaneous reduction of nitrate and selenate by cell suspensions of selenium-respiring bacteria. Appl. Environ. Microbiol. 65, 4385-4392.

Oremland, R. S., Blum, J. S., Culbertson, C. W., Visscher, P. T., Miller, L. G., Dowdle, P., et al. (1994). Isolation, growth, and metabolism of an obligately anaerobic, selenate-respiring bacterium, strain SES-3. Appl. Environ. Microbiol. 60, 3011-3019.

Park, C. H., Keyhan, M., Wielinga, B., Fendorf, S., and Matin, A. (2000). Purification to homogeneity and characterization of a novel Pseudomonas putida chromate reductase. Appl. Environ. Microbiol. 66, 1788-1795.

Pattanapipitpaisal, P., Brown, N. L., and Macaskie, L. E. (2001). Chromate reduction and 16S rRNA identification of bacteria isolated from a $\mathrm{Cr}(\mathrm{VI})$-contaminated site. Appl. Microbiol. Biotechnol. 57, 257-261.

Ramírez-Díaz, M., Díaz-Pérez, C., Vargas, E., Riveros-Rosas, H., CamposGarcía, J., and Cervantes, C. (2008).
Mechanisms of bacterial resistance to chromium compounds. Biometals 21, 321-332.

Saltzman, B. E. (1952). Microdetermination of chromium with diphenylcarbazide by permanganate oxidation. Anal. Chem. 24, 1016-1020.

Saraiva, L. M., Da Costa, P. N., and Legall, J. (1999). Sequencing the gene encoding Desulfovibrio desulfuricans ATCC 27774 nine-heme cytochrome c. Biochem. Biophys. Res. Commun. 262, 629-634.

Senko, J., and Stolz, J. F. (2001). Evidence for iron-dependent nitrate reduction in the dissimilatory ironreducing bacterium Geobacter metallireducens. Appl. Environ. Microbiol. 67, 3750-3752.

Shevchenko, A., Tomas, H., Havlis, J., Olsen, J. V., and Mann, M. (2006). In-gel digestion for mass spectrometric characterization of proteins and proteomes. Nature Prot. 1, 2856-2860.

Sparacino, C. E., Chovanec, P., Stolz, J. F., and Basu, P. (2008). Structure predication and purification of periplasmic nitrate reductase from Sulfurospirillum barnesii. INOR571. Pittsburgh: American Chemical Society.

Sparacino-Watkins, C. E. (2011). Nitrate metabolism in the Epsilonproteobacteria: Campylobacter jejuni and Sulfurospirillum barnesii. Ph.D, Duquesne University, Pittsburgh.

Stolz, J. F., and Basu, P. (2002). Evolution of nitrate reductase: molecular and structural variations on a common function. Chembiochem. 3 , 198-206.

Stolz, J. F., Ellis, D. J., Blum, J. S. Ahmann, D., Lovley, D. R., and Oremland, R. S. (1999). Sulfurospirillum barnesii sp. nov. and Sulfurospirillum arsenophilum sp. nov., new members of the Sulfurospirillum clade of the epsilon Proteobacteria. Int. J. Syst. Bacteriol. 49(Pt 3), 1177-1180.
Stolz, J. F., Gugliuzza, T., Blum, J. S., Oremland, R., and Murillo, F. M. (1997). Differential cytochrome content and reductase activity in Geospirillum barnesii strain SeS3. Arch. Microbiol. 167, 1-5.

Stolz, J. F., and Oremland, R. S. (1999) Bacterial respiration of arsenic and selenium. FEMS Microbiol. Rev. 23, 615-627.

Suzuki, T., Miyata, N., Horitsu, H., Kawai, K., Takamizawa, K., Tai, Y., et al. (1992). NAD(P)H-dependent chromium (VI) reductase of Pseudomonas ambigua G-1: a $\mathrm{Cr}(\mathrm{V})$ intermediate is formed during the reduction of $\mathrm{Cr}(\mathrm{VI})$ to $\mathrm{Cr}(\mathrm{III})$. $J$. Bacteriol. 174, 5340-5345.

Turick, C. E., Apel, W. A., and Carmiol, N. S. (1996). Isolation of hexavalent chromium-reducing anaerobes from hexavalentchromium-contaminated and noncontaminated environments. Appl. Microbiol. Biotechnol. 44 683-688.

Viamajala, S., Peyton, B. M., Apel, W. A., and Petersen, J. N. (2002a). Chromate reduction in Shewanella oneidensis MR-1 is an inducible process associated with anaerobic growth. Biotechnol. Prog. 18, 290-295.

Viamajala, S., Peyton, B. M., Apel, W. A. and Petersen, J. N. (2002b). Chromate/nitrite interactions in Shewanella oneidensis MR-1: evidence for multiple hexavalent chromium [Cr(VI)] reduction mechanisms dependent on physiological growth conditions. Biotechnol. Bioeng. 78 770-778.

Wielinga, B., Mizuba, M. M., Hansel, C. M., and Fendorf, S. (2001). Iron promoted reduction of chromate by dissimilatory iron-reducing bacteria. Environ. Sci. Technol. 35, 522-527.

Xu, L., Luo, M., Jiang, C., Wei, X., Kong, P., Liang, X., et al. (2012). In vitro reduction of hexavalent chromium by cytoplasmic fractions of Pannonibacter phragmitetus LSSE-09 under aerobic and anaerobic conditions. Appl. Biochem. Biotechnol. 166, 933-941.

Yang, C., Cheng, Y., Ma, X., Zhu, Y., Holman, H. Y., Lin, Z., et al. (2007). Surface-mediated chromateresistant mechanism of Enterobacter cloacae bacteria investigated by atomic force microscopy. Langmuir 23, 4480-4485.

Zhang, N. (2012). Chromate Reduction by Desulfovibrio desulfuricans ATCC 27774. MS thesis, Duquesne University, Pittsburgh.

Zumft, W. G. (1997). Cell biology and molecular basis of denitrification. Microbiol. Mol. Biol. Rev. 61, 533-616.

Conflict of Interest Statement: The authors declare that the research was conducted in the absence of any commercial or financial relationships that could be construed as a potential conflict of interest.

Received: 18 July 2012; accepted: 19 November 2012; published online: 17 December 2012.

Citation: Chovanec $P$, SparacinoWatkins C, Zhang N, Basu P and Stolz JF (2012) Microbial reduction of chromate in the presence of nitrate by three nitrate respiring organisms. Front. Microbio. 3:416. doi: 10.3389/fmicb.2012.00416

This article was submitted to Frontiers in Microbiological Chemistry, a specialty of Frontiers in Microbiology.

Copyright (C) 2012 Chovanec, SparacinoWatkins, Zhang, Basu and Stolz. This is an open-access article distributed under the terms of the Creative Commons Attribution License, which permits use, distribution and reproduction in other forums, provided the original authors and source are credited and subject to any copyright notices concerning any third-party graphics etc. 